\title{
Fungal endocarditis with right ventricular candidal mycetoma in a premature neonate
}

\author{
Jayashree Purkayastha', Leslie Edward Lewis ${ }^{1}$, Ramesh Bhat Y, Morakhia Jwalit V², Ranjan Shetty K², \\ Muhammad Najih L ${ }^{1}$ \\ ${ }^{1}$ Department of Paediatrics, Kasturba Medical College, Manipal University, Manipal, Karnataka, India \\ ${ }^{2}$ Department of Cardiology, Kasturba Medical College, Manipal University, Manipal, Karnataka, India
}

\begin{abstract}
Fungal mycetoma or endocarditis is rare in premature neonates and it is often associated with high mortality. In the majority of the cases diagnosis is made postmortem. Here we report a 30-week-old preterm neonate who developed Candida albicans blood stream infection complicated by endocarditis and subsequent mycetoma. Initially, this neonate had Klebsiella sepsis requiring multiple antibiotic courses. A peripherally inserted central venous catheter was used to give total parenteral nutrition. On day 24 of life, he developed candidemia, treated with 14 day course of fluconazole and shown improvement. Further, on day 60 of life he developed cholestasis, deranged liver function tests and persistent thrombocytopenia along with apnea, bradycardia and desaturations. Blood culture again grew again C. albicans. Echocardiography showed large fungal vegetation on tricuspid valve with a mycetoma filling the right ventricle. He was treated with intravenous amphotericin $B$, fluconazole and supportive measures, but he deteriorated and succumbed after two weeks. J Microbiol Infect Dis 2015;5(3): 142-145
\end{abstract}

Key words: Prematureneonate, candida sepsis, endocarditis, mycetoma

\section{Prematüre yenidoğanda sağ ventrikülde kandida miçetoma ile mantar endokarditi}

\section{ÖZET}

Prematür yenidoğanlarda mantar miçetoma nadirdir ve sıklıkla mortaliteyle sonuçlanır. Olguların çoğunda tanı postmortem konulur. Burada Candida albicans ile kan dolaşımı enfeksiyonu gelişen, ardından endokardit ve miçetoma ile komplike olan 30 haftalık preterm bir yenidoğan olgusunu sunduk. Bu yenidoğanın başlangıçta çoklu antibiyotik kullanmayı gerektiren Klebsiella sepsisi vardı. Total parenteral beslenme için periferden konulan bir santral venöz kateter kullanıldı. Doğumdan sonraki 24. günde kandidemi gelişti, 14 gün süreyle flukonazol ile tedavi edildi ve iyileşme gösterdi. Daha sonra 60. günde kolestaz gelişti ve bozulan karaciğer fonksiyon testleri ve sürekli trombositopeni ile birlikte apne, bradikardi ve satürasyon bozuklukları ortaya çıktı. Kan kültüründe tekrar C. albicans üredi. Ekokardiyografide sağ ventrikülü dolduran bir miç̧etoma ile triküspid kapak üzerinde büyük bir mantar vejetasyonu görüldü. Damar yoluyla amfoterisin B ve flukonazol tedavisi yanında diğer gereken tıbbı destekler yapıldı ancak hastanın genel durumu bozularak iki hafta sonra kaybedildi.

Anahtar kelimeler: Prematür yenidoğan, candida sepsisi, endokardit, miçetoma

\section{INTRODUCTION}

Fungal mycetoma or endocarditis in neonates and children is associated with increased morbidity and mortality with diagnosis in majority of cases made post mortem. ${ }^{1}$ It is a rare occurrence in premature neonates with more than $50 \%$ mortality and signifi- cant morbidity regardless of the type of treatment. Candida albicans accounts for nearly two third of fungal endocarditis. ${ }^{2}$ Here we report a case of fungal endocarditis complicated by mycetoma in a premature neonate who succumbed in spite of aggressive treatment. 


\section{CASE}

A 30-week old, male, preterm ,appropriate for gestational age neonate was born by emergency lower segment caesarian section (LSCS) complicated by respiratory distress syndrome requiring transfer to the neonatal intensive care unit (NICU). The neonate was subsequently intubated and given inhaled surfactant. His birth weight was $1300 \mathrm{~g}$; length:36 $\mathrm{cm}$ and head circumference: $26 \mathrm{~cm}$. He was extubated on day 2 of life and connected to nasal continuous positive airway pressure (CPAP). Total parenteral nutrition (TPN) was given through peripherally inserted central venous catheter (PICC) and trophic feeds were started. On day 10 of life, he developed frequent apnea, bradycardia and per-os feed intolerance requiring continuation of TPN. Blood culture drawn at that time grew Klebsiella pneumoniae. Cerebrospinal fluid analysis (CSF) was normal. He was treated with Piperacillin/Tazobactam and Amikacin initially, after 7 days in view of poor clinical response, the baby had frequent apnea, bradycardia and desaturations, and repeat blood c/s was sent which again grew Klebsiella hence antibiotics were changed to Cefoperazone/Sulbactam and Ciprofloxacin. On day 23 of life platelet counts dropped from $140,000 / \mathrm{mm}^{3}$ to $5,000 / \mathrm{mm}^{3}$ with Haemoglobin of 9 $\mathrm{gm} / \mathrm{dl}$. Platelets and packed red blood cells transfusions were given. Blood c/s done at this point of time revealed growth of Candida albicans sensitive to fluconazole and amphotericin B. Echocardiography done to rule out fungal vegetation revealed $2 \mathrm{~mm}$ ventricular septal defect (VSD) and a PFO with no significant shunting. Ophthalmological examination done to rule out fungal infection and also for retinopathy of prematurity was normal. Urine for fungal hyphae was positive. Ultrasonography of abdomen done to rule out renal pathology was normal. Cranial ultrasound done to rule out intraventricular hemorrhage was normal.

Intravenous Fluconazole was started on day 24 of life, as soon as the blood c/s was positive for Candida albicans (12 mg/kg loading dose followed

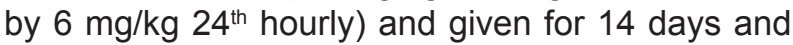
blood culture at the end of therapy, day 40 of life was sterile. Platelet counts had improved. He had shown clinical improvement, tolerated feeds well and started taking breast feeds on day 40 of life. PICC line was removed but tip was not sent for $\mathrm{c} / \mathrm{s}$ as blood c/s at that point of time was sterile.
On day 45 , he was noticed to have neonatal cholestasis with deranged liver function tests (Total bilirubin of $12 \mathrm{mg} / \mathrm{dl}$, direct bilirubin $10.7 \mathrm{mg} / \mathrm{dl}$, AST $489 \mathrm{IU} / \mathrm{L}$, ALT $143 \mathrm{IU} / \mathrm{L}$, Albumin $2.8 \mathrm{gm} / \mathrm{dl}$ ). TORCH titers done were negative however urine Cytomegalovirus (CMV) DNA-PCR was positive. This cholestasis could be due to CMV infection or due to fluconazole therapy or might be related to TPN. The baby was started on multivitamins, Vitamin $\mathrm{K}$ and ursodeoxycholic acid. On day 60 of life he again developed apnea, bradycardia and desaturation. Platelet counts dropped to $36,000 / \mathrm{mm}^{3}$ from $100,000 / \mathrm{mm}^{3}$. Arterial blood gas (ABG) analysis revealed metabolic acidosis. Repeat blood culture grew $C$. albicans with same sensitivity pattern as earlier. Baby had frequent apnea, bradycardia and desaturation with $A B G$ revealing hypoxia and hypercarbia hence was intubated and ventilated, started on intravenous amphotericin B deoxycholate at $0.5 \mathrm{mg} / \mathrm{kg} / \mathrm{day}$ and increased to $1.5 \mathrm{mg} / \mathrm{kg} /$ day subsequently. Repeat echocardiography evaluation done revealed large tricuspid valve vegetations and an echogenic mass $(1.8 \times 0.9 \mathrm{~cm})$ causing significant obliteration of right ventricular cavity, mycetoma (Figure 1) resulting in a right to left shunting through PFO (Figure 2 and 3). A diagnosis of candidal endocarditis with right ventricular mycetoma was made. Repeat CSF analysis was normal. Urine grew C. albicans. With amphotericin B, fluconazole, mechanical ventilation and other supportive therapy baby had fluctuating clinical course. A repeat echocardiography done 6 days later, day 73 of life, showed no significant regression of the mycetoma. Baby finally succumbed on day 76 of life.

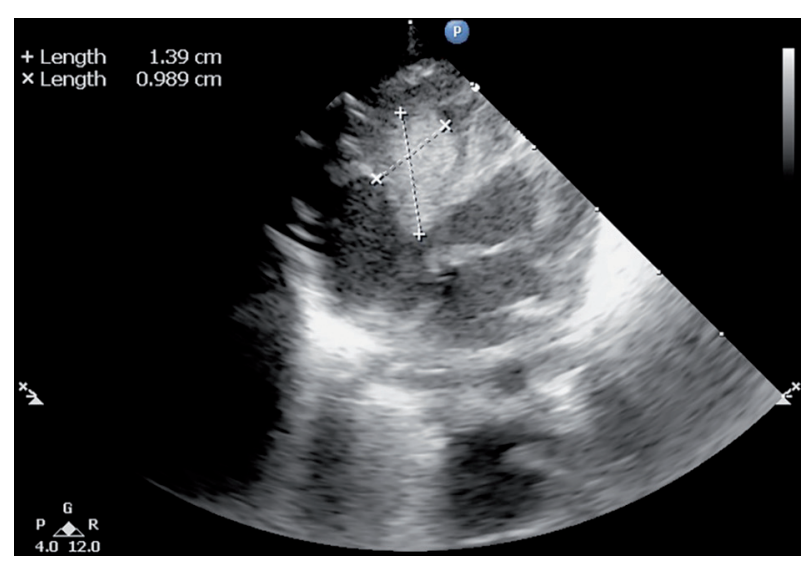

Figure 1. Right ventricle mycetoma. 


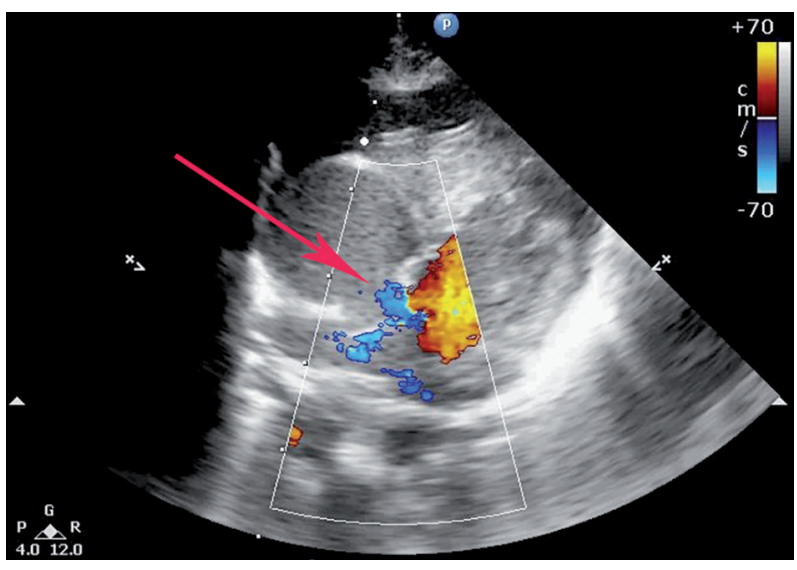

Figure 2. Right to left shunting across PFO (arrow).

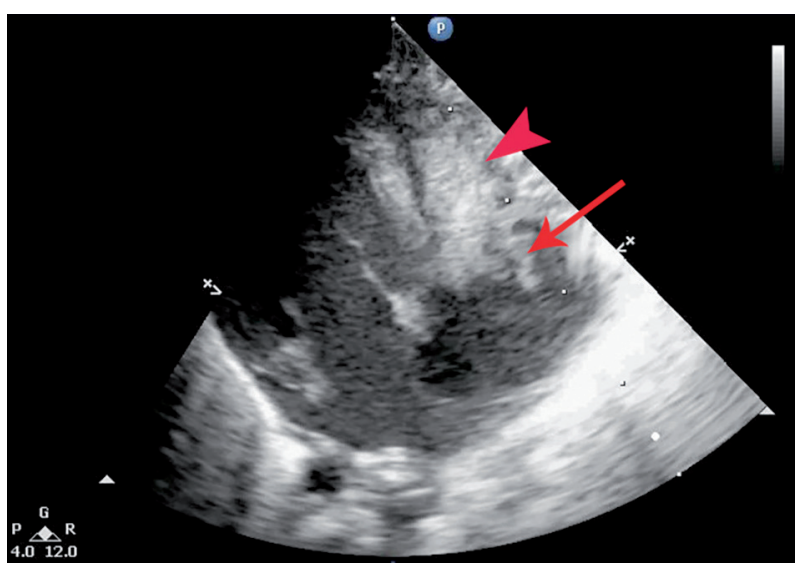

Figure 3. Parasternal RV inflow view showing RV mycetoma (arrowhead), TV vegetation (arrow).

\section{DISCUSSION}

Fungal infections are not common in healthy neonates. The predisposing factors for fungal infections in neonates include prematurity, very low birth weight, central or peripherally inserted vascular catheters, endotracheal tube, broad spectrum antibiotics, total parenteral nutrition. Candida species usually cause fungal infections in newborn and presence of above risk factors can lead to disseminated candidiasis. Invasive infection of the blood with Candida spp. leads to dissemination most commonly to heart, kidney, eyes and liver. Cardiac involvement is reported in $15.2 \%$ neonates with candidemia and vegetations often are larger and more likely to embolise than those observed with bacterial endocarditis, they usually present with hypotension, bradycardia and acute respiratory distress requiring intubation. ${ }^{2}$ Presence of simultaneous bacteremia and candidemia was associated with a greater likelihood for an abnormal echocardiogram as seen in a study by Noyola et al. ${ }^{3}$ However mycetoma formation as observed in our patient has been noted only in $9 \%$ cases. $^{2}$ In the present case, the neonate had most of the risk factors for candidiasis. Initial candida sepsis was treated effectively with intravenous fluconazole and repeat blood culture was sterile. The neonate had candida sepsis again with endocarditis and mycetoma formation which could have been mistaken for a neoplasm otherwise. The typical manifestations of fungal endocarditis such as bradycardia, apnea and respiratory distress were observed in the present case. The neonate also required intubation and mechanical ventilation. However it was unlikely that it was Klebsiella endocarditis because Klebsiella endocarditis is very rare and last 3 blood c/s was clear of the pathogen hence synergistic action of Klebsiella and candida was not thought of.

Although the condition is usually associated with high mortality survival has been reported with candidal endocarditis. ${ }^{4}$ Survival rate of candidal endocarditis was $73.1 \%$ in a study and review of literature done by Levy et al $(n=30) .{ }^{5}$ In neonates antibiotic therapy alone has been noted to have success in comparison with antibiotics and surgery in adults. ${ }^{5}$ Study by Noyola et al. recommends amphotericin B alone without surgical intervention in the treatment of candida endocarditis. ${ }^{3}$ We treated the neonate with amphotericin B and fluconazole based on sensitivity report. Surgical consultation was not sought because the baby was sick and would not tolerate surgery. Micafungins were not used because they should be used with caution and generally limited to situations in which resistance or toxicity preclude the use of fluconazole or amphotericin $\mathrm{B}$, besides study of micafungins in neonates is limited hence use of micafungins in this case was not thought of.

Because of high mortality associated with fungal endocarditis prevention has a greater role. A high index of suspicion, early mycological diagnosis in the presence of risk factors, early amphotericin $B$ (with or without flucytosine) and enforcement of strict infection control measures are important to decrease the incidence of fungal opportunistic infection in neonates. ${ }^{6}$ In nurseries with high rates of invasive candidiasis fluconazole prophylaxis may be considered in neonates whose birth weight is $<1000 \mathrm{~g}$. Antifungal drug resistance, drug related toxicity and neurodevelopmental outcomes should be observed. ${ }^{7}$ 
This case is unique because initial candida sepsis was treated with fluconazole and after 14 days blood c/s was sterile. Initial echocardiogram was also normal however the neonate got repeat candida infection complicated by fungal endocarditis and mycetoma formation hence a role of surveillance echocardiography is important in neonates with candida bloodstream infection. In spite of aggressive therapy with amphotericin B and fluconazole, baby succumbed and there was no regression of mycetoma. Initially we treated the baby only with fluconazole, whether initiation of amphotericin $B$ at earlier stage could have prevented the mortality needs to be pondered on. As growth of Candida spp. both the times were same and sensitive to both fluconazole and amphotericin $B$, use of micafungins was not entertained.

Though neonatal candidal endocarditis has better chance of survival than in adults we could not salvage this neonate, perhaps associated Klebsiella sepsis and CMV infection contributed to the mortality.

\section{REFERENCES}

1. Millar BC, Jugo J, Moore JE. Fungal endocarditis in neonates and children. Pediatr Cardiol 2005;26:517-536.

2. Sharma J, Nagaraj A, Allapathy D, et al. Fungal endocarditis in a prematureinfant complicated by a right atrial mycetoma and IVC thrombosis. Images Pediatr Cardiol 2009;11:6-11.

3. Noyola DE, Fernandes M, Moylett E, Baker CJ. Ophthalmologic, visceral and cardiac involvement in neonates with candidemia. Clin Infect Dis 2001;32:1018-1032.

4. Citak M, Rees A, Mavroudis C. Surgical management of infective endocarditis in children. Ann Thorac Surg 1992;54:755760.

5. Levy I, Shalit I, Birk E, et al. Candida endocarditis in neonates: report of five cases and review of the literature. Mycoses 2006;49:4.

6. Emilio M, Jose M, Juan C, Guarro Josep G. Fungal endocarditis in Premature Infant. Case Report and Review. Clin Infect Dis. 1996;22:366-368.

7. Pappas GP, Kauffman AC, Andes D, et al. Clinical Practice Guidelines for the management of Candidiasis: 2009 Update by the Infectious Diseases Society of America. Clin Infect Dis 2009;48:503-535. 